\title{
SINTESIS ZEOLIT A DAN KEMUNGKINAN PENGGUNAANNYA SEBAGAI PENUKAR KATION
}

\author{
Sriatun \\ Laboratorium Kimia Anorganik \\ Jurusan KimiaFMIPA UNDIP \\ J1. Prof. Soedarto, SH Tembalang Semarang 50275
}

\begin{abstract}
ABSTRAK
Telah dilakukan sintesis zeolit A dengan menggunakan alumunium hidroksida sebagai sumber alumina dan silikon dioksida sebagai sumber silika. Sintesis dilakukan dengan cara mereaksikan natrium silikat dan natrium aluminat melalui proses hidrotermal dalam sistem dengan pH 11-12. Karakterisasi produk sintesis dilakukan dengan menggunakan spektrometer infra merah (IR) dan difraktometer sinar-x (XRD). Dari hasil analisis data IR diperoleh informasi bahwa rasio Si/Al dalam zeolit hasil sintesis adalah tinggi. Uji kualitas kristal (kristalinitas) menunjukkan adanya pergeseran sudut difraksi pada puncak-puncak khas zeolit A, ini mengindikasikan bahwa penataan polihedral sangkar sodalit belum seluruhnya sempurna. Kondisi $\mathrm{pH}$ optimum untuk pertukaran kation $\mathrm{Ca}^{2}$ terhadap zeolit hasil sintesis adalah 6.
\end{abstract}

Kata Kunci: Zeolit A, sintesis, penukar kation

\section{SYNTHESIS OF ZEOLITE A AND THE OPPURTUNITY AS A CATION EXCHANGE}

\begin{abstract}
The synthesis of zeolite A was done by using alumunium hydroxide as a source of alumina and silicon dioxide as a source of silica. The synthesis was done by reacting sodium silicate and sodium aluminate through hydrothermal process at $p H=11-12$. Characterization of product of synthesis were carried out by using IR spectrometer and X-ray Difractometer.From the analysis result of IR data, we got any information that the Si/Al ratio onto zeolite from synthesis was high The crystal quality test (crystalinity) showed that there were moving of diffraction angles on characteristic peak of zeolite A. This case indicated that arrangging of polyhedral sodalit cages not completed yet. The optimum condition of the cation exchange of $\mathrm{Ca}^{2+}$ towards product synthesis was occurred on $\mathrm{pH} 6$.
\end{abstract}

Key words: Zeolit A, synthesis, cation exchange

\section{PENDAHULUAN}

Zeolit merupakan mineral alam yang terbentuk melalui proses geologi yang secara alami memerlukan waktu yang panjang. Pada kondisi ini variabel termodinamika seperti tekanan, temperatur, waktu dan komposisi penyusunnya turut mempengaruhinya. Dalam proses hidrotermal, variabel-variabel tersebut tidak mutlak menentukan produk karena campuran reaktan yang digunakan kemungkinan heterogen, selain itu proses nukleisasi (pembentukan inti) lebih dikendalikan oleh variabel kinetika (Barrer, 1982).

Struktur zeolit adalah tiga dimensi, hal ini menguntungkan karena tidak mengalami perubahan dimensi jika terjadi pertukaran ion. Menurut Arryanto (2001) pertukaran ion adalah suatu proses di mana ion dari satu sistim ditukar dengan ion dari sistim lain.

Penggunaan zeolit alam sebagai penukar kation kadang-kadang memberikan kesukaran karena kemungkinan besar mengandung logam-logam lain, sehingga dapat mengakibatkan adanya kompetisi pertukaran dengan logam yang tidak diinginkan. Untuk menghindarinya dan untuk mengefektifkan pertukaran perlu dibuat zeolit sintetis yang mempunyai komposisi jelas seperti zeolit A. Dalam penelitian ini diupayakan pembuatan zeolit A dari bahan alumina dan silika melalui proses hidrotermal, selanjutnya 
zeolit hasil sintesis diujicobakan terhadap pertukaran kation $\mathrm{Ca}^{2+}$ dengan harapan dapat digunakan untuk menangani masalah kesadahan air.

\section{METODE PENELITIAN}

\section{Tahap I: Sintesis Zeolit A}

Natrium aluminat dibuat dengan cara: natrium hidroksida 30,5 gram dilarutkan dengan akuades sampai volumenya $100 \mathrm{ml}$, kemudian dipanaskan. Selanjutnya ditambah dengan alumunium hidroksida 21,6 gram sambil diaduk dan diencerkan hingga volumenya $250 \mathrm{ml}$.

Pembuatan zeolit A dilakukan dengan cara $8 \mathrm{ml}$ natrium hidroksida dalam bejana teflon kemudian ditambah natrium aluminat sebanyak $6 \mathrm{ml}$ secara bertetes-tetes sambil diaduk selama 10 menit. Campuran ditambah $6 \mathrm{ml}$ natrium silikat secara bertetes-tetes dan diaduk selama 5 menit (rasio jumlah garam alumniat dan garam silikat adalah 1:1). Campuran ditambah akuades $10 \mathrm{ml}$ dan diaduk selama 10 menit. Proses hidrotermal dilakukan dengan cara bejana teflon ditutup dan dipanaskan pada temperatur $100{ }^{\circ} \mathrm{C}$ selama 5 jam. Selanjutnya didiamkan semalam. Kristal yang diperoleh dicuci hingga eluatnya netral, selanjutnya dikeringkan hingga beratnya konstan.

\section{Tahap II: Karakterisasi hasil}

Uji kualitatif terhadap produk sintesis pada penelitian ini meliputi:

1. IR untuk mengetahui tingkat kesempurnaan pembentukan D4R yang merupakan ciri khas struktur zeolit A dan pembentukan $\mathrm{TO}_{4}$ $\left(\mathrm{SiO}_{4}^{4-}\right.$ dan $\left.\mathrm{AlO}_{4}{ }^{5-}\right)$.

2. XRD untuk mendapatkan gambaran mikrostruktur kristal yang terbentuk.

Tahap III: Modifikasi zeolit hasil sintesis dengan Amonium karbonat

Agar zeolit hasil sintesis ini dapat digunakan sebagai bahan penukar kation $\mathrm{Ca}^{2+}$, kation $\mathrm{Na}^{+}$ harus ditukar dulu dengan $\mathrm{H}^{+}$. Prosedurnya adalah sebagai berikut: Zeolit hasil sintesis direndam dalam amonium karbonat $1 \mathrm{M}$ sambil digojog menggunakan shaker (sistim batch shaker) selama 24 jam. Kemudiam didiamkan semalam, disaring dan dikalsinasi pada temperatur $450^{\circ} \mathrm{C}$ selama 2 jam.

Tahap IV: Penggunaan zeolit hasil sintesis sebagai bahan penukar kation $\mathrm{Ca}^{2+}$

Pada tahap ini akan dikaji pengaruh $\mathrm{pH}$ terhadap kemampuan pertukaran kation $\mathrm{Ca}^{2+}$. Prosedurnya adalah sebagai berikut: Sebanyak 0,5 gram zeolit hasil sintesis ditambah $25 \mathrm{ml}$ akuades pada $\mathrm{pH}$ yang bervariasi. Selanjutnya ditambah $25 \mathrm{ml} \mathrm{CaCl}_{2}$ 0,1 M, digojog dengan sistim batch shaker selama 9 jam dan direndah semalam. Untuk mengetahui titik ekivalennya, filtrat diambil sebanyak $10 \mathrm{ml}$ ditambah indikator $\mathrm{pp}$, dititrasi dengan $0,01 \mathrm{~m}$ larutan natrium hidroksida.

\section{Tahap V: Interpretasi dan pengolahan data}

1. Interpretasi spektogram IR dan difraktogram sinar-X zeolit hasil sintesis.

2. Analisis pengaruh $\mathrm{pH}$ terhadap kemampuan pertukaran kation $\mathrm{Ca}^{2+}$.

\section{HASIL DAN PEMBAHASAN}

Pada pembahasan ini akan dipaparkan hasil-hasil penelitian mengenai kajian terhadap proses sintesis, karakter zeolit hasil sintesis dan pengaruh derajat keasaman $(\mathrm{pH})$ terhadap kemampuan pertukaran kation $\mathrm{Ca}^{2+}$.

\section{Kajian terhadap proses sintesis}

Pada bagian ini akan dibahas mengenai pembentukan kristal zeolit pada proses sintesis. Pada penelitian ini, metode perlakuan mengacu pada penelitian-penelitian yang pernah dilakukan sebelumnya, hanya saja kondisi hidrotemal yang berbeda. Baik Kartini (1997) maupun Hadi (1993) menggunakan kondisi suhu hidrotermal $200{ }^{\circ} \mathrm{C}$, sedangkan pada penelitian ini digunakan suhu yang lebih rendah yaitu 100 ${ }^{\circ} \mathrm{C}$ agar lebih efisien. Ternyata hasil yang diperoleh cukup baik. Pemanasan ini bertujuan untuk menyempurnakan pertumbuhan kristal 
yang telah dimulai sejak adanya interaksi antara garam aluminat dan garam silikat.

Pada penelitian ini $\mathrm{pH}$ sistim tetap menggunakan pH 11-12, karena kondisi ini berhubungan dengan keberadaan spesies $\mathrm{Si}_{4} \mathrm{O}_{8}(\mathrm{OH})_{4}{ }^{4-}$ dan $\mathrm{Al}(\mathrm{OH})_{4}^{-}$. Spesies-spesies tersebut yang berinteraksi membentuk polimer silika alumina, jadi akan mempengaruhi laju nukleisasi dan pertumbuhan kristal (Hamdan, 1992 dan Arryanto, 2001).

Pada tingkat kebasaan yang berbeda akan ditemukan spesies yang berbeda pula. Jadi jenis anion yang ada dikendalikan oleh $\mathrm{pH}$ larutan. Dalam larutan asam dengan $\mathrm{pH}$ 1-4 kation alumunium oktahedral $\left[\mathrm{Al}\left(\mathrm{H}_{2} \mathrm{O}\right)_{6}\right]^{3+}$ yang dominan. Pada range $\mathrm{pH}$ 2-6 kation oksialumunium juga ada. Spesies aluminat yang berkaitan dengan pembentukan polimer silika alumina adalah $\mathrm{Al}(\mathrm{OH})_{4}^{-}$, di mana konsentrasi maksimalnya dapat ditemukan pada $\mathrm{pH}=9$ atau di atasnya. Konsentrasi optimum spesies $\mathrm{Si}^{4+}$ berada pada $\mathrm{pH}=11$ atau $\mathrm{pH}=12$. Dengan mempertimbangkan kedua keadaan tersebut, maka proses sintesis dilakukan pada pada 11-12, sehingga diharapkan reaksi yang terjadi adalah optimum.

Pada proses interaksi spesies aluminat dan silikat ini diperoleh gel berwarna putih, ini menunjukkan adanya interaksi yang kuat antara kedua yang berarti dimulainya proses penggandengan (polimerisasi) silikat dan aluminat. Pembentukan kristal zeolit terjadi saat kondensasi disertai polimerisasi (pembentukan rantai yang panjang) spesies aluminat dan silikat dalam larutan lewat jenuh. Pada pencampuran sodium silikat dan sodium aluminat terbentuk dua fasa yaitu fasa padat sebagai gel amorf dan fasa larutan sebagai larutan lewat jenuh. Kedua fasa tersebut berada pada kesetimbangan. Gel amorf akan larut dan mengalami penataan struktur kembali untuk membentuk spesies yang merupakan bibit inti kristal dan merupakan tahap nukleisasi.

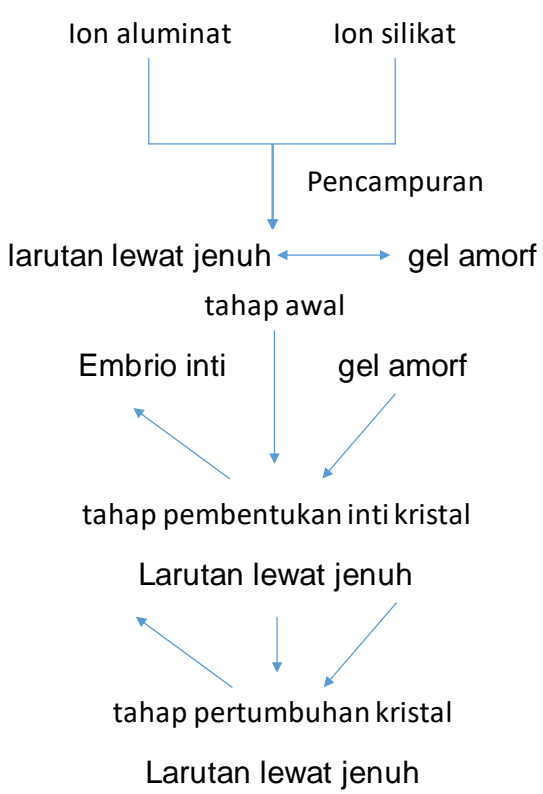

Gambar 1. Skema mekanisme pembentukan zeolit sintetis

Pada tahapan ini dalam larutan terdapat kesetimbangan antara bibit inti kristal gel amorf sisa dan larutan lewat jenuh. Jika gel sisa larut, akan terjadi pertumbuhan kristal hingga gel terlarut sampai habis. Gel putih hasil interaksi aluminat-silikat dalam bejana teflon selanjutnya dipanaskan pada suhu $100{ }^{\circ} \mathrm{C}$ selama 5 jam untuk menyempurnakan pertumbuhan kristal, dan pada akhirnya diperoleh padatan putih untuk dikarakterisasi selanjutnya. Pembentukan kristal zeolit dapat diilustrasikan seperti gambar 3.1 di atas.

\section{Karakterisasi Padatan Hasil Sintesis}

\section{Interpretasi spektra infra merah (IR)}

Pada penelitian ini salah satu karakterisasi produk hasil sintesis dilakukan dengan spektroskopi inframerah, karena dengan metode ini dapat diketahui karakter strukturnya. Dari sini akan diperoleh informasi tentang panjang pendeknya ikatan yang disebabkan oleh lattice coupling electrotatic dan pengaruh lainnya. Frekuensi vibrasi daerah tengah/sedang inframerah adalah 300-1300 $\mathrm{cm}^{-1}$. Pada daerah ini memberikan informasi tentang komposisi dan kondisi tetrahedral $\mathrm{SiO}_{4}{ }^{4-}$ atau $\mathrm{AlO}_{4}{ }^{5-}$ pada zeolit hasil sintesis. Menurut Hamdan (1992) penetapan frekuensi inframerah terhadap sifat- 
sifat struktur maupun karakterisasinya didasarkan pada kerja FKS. Pada umumnya perlakuan FKS pada spektra inframerah daerah tengah suatu zeolit mengandung dua tipe vibrasi. Hamdan juga mengungkapkan bahwa untuk tipe zeolit A terdapat pada daerah tengah inframerah antara $1500-400 \mathrm{~cm}^{-1}$ yang dibagi menjadi lima daerah utama, masing-masing berhubungan dengan spesifikasi jenis dari model vibrasi. Zeolit A merupakan polimer silika alumina dengan karakter utama double 4 ring (D4R) dan ikatan Si-O dan Al-O.

Semua pita yang disebabkan oleh vibrasi internal dalam kerangka adalah sensitif terhadap struktur dan komposisi kerangka. Dengan naiknya kandungan $\mathrm{Si}$, intensitas pita dekat $568 \mathrm{~cm}^{-1}$ berkurang dan bergeser ke frekuensi yang lebih tinggi. Vibrasi kerangka juga sensitif terhadap jenis dan muatan kation penyeimbang muatan.

Jika spektra produk sintesis dibandingkan dengan spektra zeolit-A standar terdapat pergeseran frekuensi rentangan $\mathrm{O}-\mathrm{Si}-\mathrm{O}$ atau $\mathrm{O}$ Al-O dan cincin ganda beranggota 4 (D4R) ke frekuensi yang lebih tinggi. Hal ini menunjukkan bahwa kandungan Si padatan hasil sintesis yang relatif besar. Ini berarti perbandingan $\mathrm{Si} / \mathrm{Al}$ dalam sintesis ini relatif besar sehingga kation penyeimbang relatif lebih kecil dibandingkan dengan standarnya yang terletak pada bilangan gelombang 995 dan $568 \mathrm{~cm}^{-1}$. Meskipun kuat, serapan cincin ganda berongga 4 (D4R) padatan hasil sintesis relatif lebih lemah dibandingkan standar, ini menunjukkan pertumbuhan kristal yang belum sempurna. Serapan pada 650-750 $\mathrm{cm}^{-1}$ yang merupakan vibrasi ulur simetrik tetrahedral internal menunjukkan bahwa tetrahedral $\mathrm{TO}_{4}$ sebagai satuan pembangun utama belum semuanya mengalami penataan membentuk polihedral sangkar sodalit atau sudah terbentuk namun ikatannya masih lemah. Sisa silikat atau aluminat yang tidak terlibat dalam pembentukan satuan pembangun utama dapat menurunkan kristalinitas.

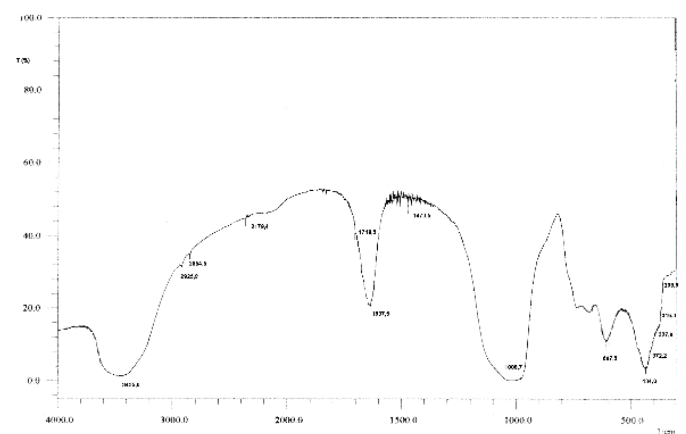

Gambar 2. Spektogram zeolit hasil sintesis

\section{Interpretasi Difraktogram XRD Padatan Hasil Sintesis.}

Karakterisasi dengan menggunakan difraksi sinar-x (XRD) merupakan hal yang vital karena digunakan sebagai identifikasi kualitatif dari zeolit. Dari pola difraktogram XRD dapat diketahui "sidik jarinya", yang memberikan informasi tentang mikrostruktur suatu kristal yaitu fasa kemurniannya dan perubahan kisi kristal. Pengukuran dilakukan dengan sudut difraksi $2 \theta=35^{\circ}-5^{\circ}$. Dalam penelitian ini difraktogram zeolit standart diambil dari Bollmoss (1984).

Kristalinitas zeolit A pembanding berbentuk kubik ditentukan oleh sepuluh puncak karakteristik pada harga d ( $\mathrm{A}) 12,305 ; 8,701$; 7,104; 5,503; 4,102; 3,710; 3,413; 3,289; 2,984; 2,623 dengan parameter sel $a_{o} \quad 24,61 \AA$ (Bollmoss, 1984). Zeolit hasil sintesis memiliki puncak khas dengan harga d ( $\AA$ ) 7,1323; 5,0251; 4,1033; 3,1652; 2,6794; 2,5174; 2,3703; 2,0452; 1,9673 dan $1,7733 . \AA$

Dari difraktogram gambar 3 tampak bahwa sudut $2 \theta$ pada zeolit hasil sintesis lebih besar dari 10. Secara rinci perbandingan data difraktogram zeolit hasil sintesis dan zeolit A standar dapat dilihat pada tabel 1. Apabila hal ini diterapkan pada persamaan Bragg sebagai berikut:

$2 \mathrm{~d} \sin \theta=\mathrm{n} \lambda$

$\mathrm{d} \sim 1 / 2 \theta$

di mana $\lambda$ adalah panjang gelombang radiasi, $d$ merupakan jarak antara tiap satuan bidang atom 
pada kisi kristal, $\theta$ adalah sudut difraksi dan $n$ tingkat difraksi. Jika sudut $2 \theta$ makin besar maka jarak d- nya makin kecil. Oleh karena pada zeolit A standar puncak pertama muncul pada sudut $2 \theta$ lebih kecil dari 10, berarti bahwa pada zeolit hasil sintesis ini memiliki jarak d yang lebih kecil daripada zeolit pembanding, dimungkinkan penataan polihedral sangkar sodalit pada produk ini belum sempurna.

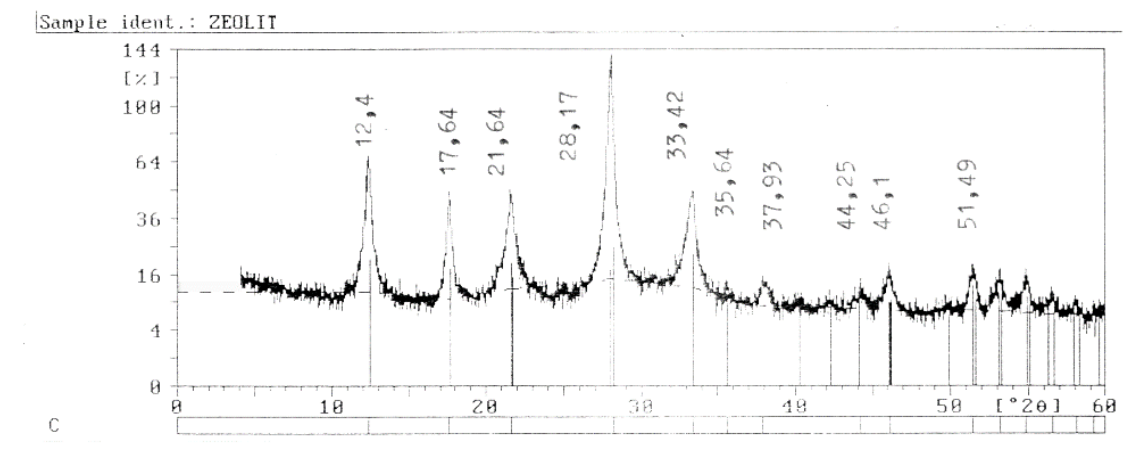

Gambar 3. Difraktogram zeolit hasil sintesis

Tabel 1. Hasil d spacing zeolit hasil sintesis dan berbagai zeolit A standar

\begin{tabular}{cccc}
\hline Jenis Padatan & $2 \theta$ & $\mathrm{d}(\AA)$ & $\mathrm{I}$ rel \\
\hline Hasil Sintesis & 12,40 & 7,132 & 54,3 \\
& 17,64 & 5,025 & 38,6 \\
& 21,64 & 4,103 & 33,8 \\
& 28,17 & 3,165 & 100,0 \\
& 33,42 & 2,679 & 34,3 \\
& 35,64 & 2,517 & 2,9 \\
& 37,93 & 2,370 & 5,3 \\
& 44,25 & 2,045 & 3,2 \\
& 46,10 & 1,967 & 9,2 \\
& 51,49 & 1,773 & 9,4 \\
\hline Zeolite A & 7,18 & 12,305 & 100.0 \\
& 10,17 & 8,701 & 54,0 \\
& 12,46 & 7,104 & 25,4 \\
& 16,11 & 5,503 & 17,8 \\
& 20,41 & 4,350 & 3,3 \\
& 21,67 & 4,102 & 26,1 \\
23,99 & 3,710 & 46,3 \\
26,11 & 3,413 & 11,3 \\
27,12 & 3,289 & 43,3 \\
29,94 & 2,984 & 47,6
\end{tabular}

\section{$34,18 \quad 2,623 \quad 34,6$}

\section{Pengaruh pH terhadap Kemampuan} Pertukaran $\mathrm{Ca}^{2+}$

Pada penelitian terdahulu baik yang telah dilakukan oleh Kartini (1997) maupun Hadi (1993) belum ada yang mengulas tentang pemanfaatan produk sintesis sebagai material penukar kation. Untuk itu dalam penelitian ini padatan hasil sintesis diujicobakan sebagai penukar kation terhadap $\mathrm{Ca}^{2+}$.

Pertukaran kation dapat terjadi karena adanya situs aktif (active site) yang merupakan bagian tidak tetap dan dapat ditukar, terikat pada atom alumunium dalam kerangka aluminasilikat. Menurut Arryanto (2001) proses pertukaran itu sendiri terjadi melalui beberapa tahap yaitu:

a. Kation yang akan ditukar dalam hal ini $\mathrm{Ca}^{2+}$ tersolvasi dan akan mendekati padatan penukar. Ini terjadi karena adanya perbedaan potensial kimia atau konsentrasi antara padatan dan larutan.

b. Kation $\mathrm{Ca}^{2+}$ akan keluar dari sistem tersolvasi dan masuk ke dalam padatan

c. Kation $\mathrm{Ca}^{2+}$ menukar $\mathrm{H}^{+}, \mathrm{H}^{+}$keluar dari padatan dan akhirnya masuk ke dalam sitem tersolvasi. 
Pada penelitian ini, banyaknya $\mathrm{H}^{+}$yang dapat menukar ditentukan dengan titrasi menggunakan $\mathrm{NaOH}$. Pada proses ini derajat keasaman berpengaruh terhadap kemampuan pertukaran $\mathrm{Ca}^{2+}$ oleh zeolit hasil sintesis. Pengaruh $\mathrm{pH}$ dapat terjadi pada sistem kesetimbangan ion dalam kerangka aluminasilikat maupun pada spesies logam yang ditukar yaitu ion kalsium. Hubungan antara kemampuan pertukaran ion $\mathrm{Ca}^{2+}$ zeolit hasil sintesis terhadap $\mathrm{pH}$ dapat dilihat pada gambar 4.

Di sini diambil kisaran $\mathrm{pH}$ antara 4 sampai 8 dengan pertimbangan dapat diaplikasikan untuk menangani kesadahan air yang biasanya mengandung ion kalsium dan derajad keasaman air yang dikomsumsi berkisar antara 4 sampai 8 . Pada $\mathrm{pH}$ di atas 8 ion kalsium akan mudah membentuk hidroksida $\mathrm{Ca}(\mathrm{OH})_{2}$ dengan Ksp $4.10^{-6}$

Zeolit dengan kerangka aluminasilikat mempunyai muatan negatif yang terdapat pada atom alumunium. Muatan negatif ini diseimbangkan oleh kation sehingga kenaikan $\mathrm{pH}$ akan menurunkan jumlah ion $\mathrm{Ca}^{2+}$ yang dapat masuk ke dalam padatan zeolit dan menggantikan $\mathrm{H}^{+}$. Hal ini terjadi karena ion $\mathrm{Ca}^{2+}$ bereaksi dengan $\mathrm{OH}^{-}$cenderung membentuk spesies hidroksida. Pada $\mathrm{pH}$ yang makin rendah, maka jumlah ion kalsium makin kecil. Hal ini terjadi karena adanya kemungkinan alumunium dalam struktur tetap mengalami dealuminasi atau berada sebagai spesies lain. Di samping itu dengan menurunnya $\mathrm{pH}$, jumlah $\mathrm{H}^{+}$dalam sistem larutan makin banyak sehingga menyebabkan rongga tempat $\mathrm{H}^{+}$terikat pada atom alumunium dalam kerangka zeolit dikelilingi oleh $\mathrm{H}^{+}$lain yang berasal dari larutan. Ini mengakibatkan ion kalsium sulit memasuki rongga.

Pertukaran kation kalsium oleh ion $\mathrm{H}^{+}$terbesar terjadi pada $\mathrm{pH}$ 6. Banyak sedikitnya ion kalsium yang dapat ditukar oleh ion hidrogen sebanding dengan jumlah ion hidrogen tersebut yang terikat oleh atom aluminium dalam kerangka zeolit. Dari sini dapat diketahui zeolit hasil sintesis ini mempunyai nisbah $\mathrm{Si} / \mathrm{Al}$ yang relatif besar. Dari hasil penelitian ini dapat dikatakan bahwa karakter produk sintesis dapat diketahui dari IR, XRD dan juga dari kajian pertukaran kation. Dengan melakukan kajian pertukaran kation diperoleh dua keuntungan yaitu informasi tentang kondisi $\mathrm{pH}$ optimal pada pertukaran dan informasi rasio $\mathrm{Si} / \mathrm{Al}$ nya meskipun masih kasar.

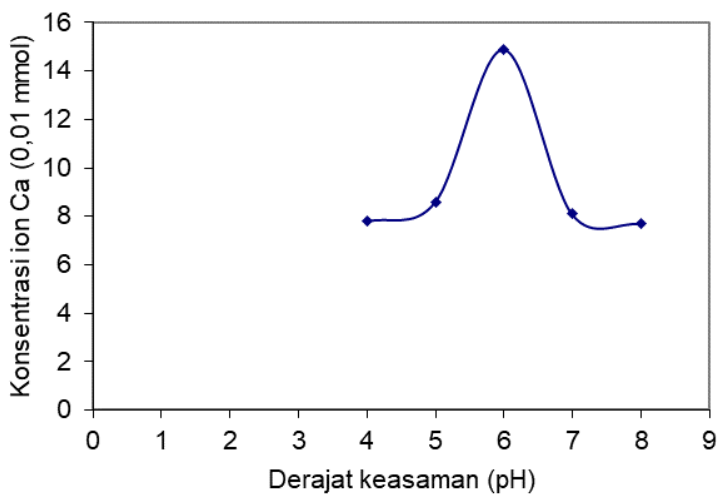

Gambar 4. Hubungan $\mathrm{pH}$ dengan konsentrasi kation penukar $\mathrm{Ca}^{2+}$

\section{KESIMPULAN}

Dari hasil penelitian yang telah dilakukan serta uraian pembahasan, dapat diambil beberapa kesimpulan sebagai berikut:

1. Proses sintesis secara hidrotermal dari natrium aluminat dan natrium silikat menghasilkan padatan berwarna putih yang merupakan kristal zeolit.

2. Zeolit hasil sintesis diduga merupakan zeolit A tetapi rasio $\mathrm{Si} / \mathrm{Al}$ dalam kerangka zeolit hasil sintesis masih relatif besar sehingga kation penyeimbang relatif sedikit. Selain itu pembentukan cincin beranggota 4 (D4R) dalam strukturnya belum sempurna.

3. Derajat keasaman optimum pada pertukaran kation $\mathrm{H}^{+}$dengan $\mathrm{Ca}^{2+}$ terdapat pada $\mathrm{pH} 6$.

\section{DAFTAR PUSTAKA}

Arryanto, Y., 2001, "Fenomena dalam Proses Pertukaran Ion", dalam Seminar Kelompok Material Anorganik Jurusan Kimia FMIPA UGM, Yogyakarta. 
Berck, D.W., 1974, "Zeolite Molecular Sieve, Structure Chemistry and Use", John Willey and Sons, New York.

Barrer, R. M, FRS, 1982, "Hydrothermal Chemistry of Zeolites", Academic Press Inc, London.

Bollmoss, R.V., 1984, "Collection of Simulated XRD Powder Pattern for Zeolites", ButterWorth, Guildford.
Hamdan, H., 1992, "Introduction to Zeolite Synthesis, Characterization and Modification", $1^{\text {st }}$ Edition, Universiti Teknologi Malaysia, Kualalumpur.

Kartini, I., 1997, "Kajian Proses dan Pengaruh Penambahan Surfaktan dalam Sintesis Zeolit A", Laporan Penelitian, Pps UGM Yogyakarta.

Hadi, S.K., 1993, "Pembuatan dan Karakterisasi Zeolit A dari Sekam Padi", Skripsi S-1 FMIPA UGM Yogyakarta. 